\title{
SHOX wt Allele
}

National Cancer Institute

\section{Source}

National Cancer Institute. SHOX wt Allele. NCI Thesaurus. Code C75404.

Human SHOX wild-type allele is located in the vicinity of Yp11.3 and within Xpter-p22.32

and is approximately $35 \mathrm{~kb}$ in length. This allele, which encodes short stature homeobox protein, plays roles in both regulation of transcription and regulation of growth.

Mutations in this gene are associated with Leri-Weill dyschondrosteosis. 